\title{
Intensitas Penggunaan Pembungkus Makanan dan Minuman di Kantin Sekitar Universitas Katolik Soegijapranata
}

\author{
Jesica Budi Priscilla \\ Universitas Katolik Soegijapranata \\ jesicabpriscilla@gmail.com \\ Devina Nathania Hamdoko \\ Universitas Katolik Soegijapranata \\ devina.nathania25@gmail.com \\ Debby Setyo \\ Universitas Katolik Soegijapranata \\ debbys.widia@gmail.com
}

\begin{abstract}
The objective of this research is to find out how many packaging can be produced each day in canteens around Unika Soegijapranata (in terms of the packaging materials they use). Respondents in this study are sellers or owners of the canteens. The number of respondents in this study were 50 canteens around Unika Soegijapranata (inside and outside Unika Segijapranata). The research method is by conducting direct interviews with open-ended questions to respondents to analyze whether the canteen around Unika Soegijapranata is already green or no, then the results of the interview are processed into quantitative data. From the results it can be seen how much the number of wrappers issued by 50 canteens in 1 day. From this study it can also be concluded that there was no canteen around the university that actually implemented green pembungkus in its business with various causes (seller awareness, weak regulation, etc.).
\end{abstract}

Keywords: Green Packaging, Green Manufacturing, Green Supply Chains

\begin{abstract}
Abstrak
Tujuan dari penelitian ini adalah untuk mengetahui seberapa banyak pembungkus yang dikeluarkan kantin di sekitar unika Seogijapranata dalam satu harinya (ditinjau dari bahan pembungkus yang digunakannya). Responden dalam penelitian ini adalah penjual atau owner dari kantin - kantin tersebut. Jumlah responden dalam penelitian ini adalah 50 kantin di sekitar unika (di dalam unika dan luar unika). Metode penelitian yang digunakan adalah dengan melakukan wawancara secara langsung dengan pertanyaan terbuka kepada responden untuk menganalisis green atau tidaknya kantin yang berada di sekitar unika tersebut. kemudian dari hasil wawancara diolah menjadi data kuantitatif. Dari hasil dapat diketahui seberapa besar jumlah pembungkus yang dikeluarkan 50 kantin yang menjadi responden dalam 1 harinya. Dari penelitian ini pula dapat disimpulkan bahwa ternyata tidak ada kantin di sekitar unika yang benar - benar menerapkan green pembungkus dalam usahanya dengan berbagai faktor penyebabnya (kesadaran penjual, lemahnya regulasi, dan lain - lain).
\end{abstract}

Kata Kunci : Green packaging, Green Manufacturing, Green Supply Chains 


\section{PENDAHULUAN}

Green business merupakan aktivitas bisnis untuk membuat input (bahan baku dan bahan penolong) menjadi output (barang dan jasa) dengan mengutamakan keseimbangan dan sinergi antara keuntungan ekonomi, social, dan lingkungan. Green business sendiri menjadi topik hangat yang menarik untuk dikaji pada akhir - akhir ini. Pentingnya green business di masyarakat menjadi salah satu faktor pendorong utama untuk mengurangi adanya dampak kerusakan lingkungan dan membantu menyadarkan masyarakat akan arti pentingnya hidup sehat akan kebutuhan produk dan jasa yang ramah lingkungan (Sulistya Rini Pratiwi 2016) .

UKM memiliki peran penting dalam green business karena jumlahnya yang banyak dan tersebar luas di seluruh penjuru dunia, terutama di Indonesia. Hal ini dikarenakan sektor UKM merupakan sektor yang memiliki hubungan paling dekat dengan masyarakat dan lingkungan. Berdasarkan data yang diambil dari Badan Pusat Statistik Indonesia serta hasil dari Sensus Ekonomi 2016 pencacahan lengkap, jumlah Usaha Mikro Kecil (UMK) di Indonesia 26,26 juta usaha. Meskipun dampak lingkungan pada tiap usaha kecil mungkin rendah, tetepi dampak agregat mereka melebihi dari bisnis besar. Misalnya, dikutip pada teori pada buku Miller, 2011; UKM Menyumbang 60 - 70\% dari polusi industri di Eropa. Sektor - sektor kunci di mana UKM memiliki dampak lingkungan yang signifikan termasuk peternakan, konstruksi, finishing logam, pengolahan limbah, makanan dan minuman industri, tekstil dan manufaktur kulit, dan lain-lain (Toolkit 2016) .

Kebanyakan dari masyarakat pada umum nya tidak terlalu memperhatikan akan adanya faktor "Green" di lingkungan sekitar. Dilihat dari buku yang dibuat oleh Sangwan dan Mittal (2015), dapat kita perhatikan sendiri bahwa pola pertumbuhan manufacturing yang berkembang secara pesat, dan terkadang sulit sekali dikendalikan maupun dihindari. Hal ini dikarenakan pola konsumsi rata - rata masyarakat secara Global terus meningkat meskipun pola konsumsi ini berbeda - beda di setiap wilayah atau pun dari berbagai daerah ke daerah tertentu yang dapat disebabkan oleh beberapa faktor seperti budaya, sosial dan ekonomi local (Rokka and Uusitalo 2008).

Konsep green business harusnya diterapkan untuk seluruh rangkaian supply chain sebuah usaha. Setiap tahap dalam supply chain, mulai dari pembelian bahan, 
prose produksi yang didalanya terdapat pengemasan, penyimpanan hingga logistik dan distribusi; memiliki peluang untuk bisa dimodifikasi dan ditingkatkan melalui prinsip-prinsip Global Supply Chain Management untuk mengurangi limbah beracun dan polusi. Namun yang sering terlihat secara empiris adalah pembungkusan, dalam Global Supply Chain (GSC) termasuk dalam green packaging. Seperti yang kita lihat pada pembungkus makanan di sekitar kita, banyak sekali bahan - bahan yang tidak termasuk dalam kriteria green packaging dan tidak sesuai dengan prinsip GSC yang ada. Hanya sedikit dari mereka yang mengubah keprihatinan ini menjadi sebuah tindakan nyata dengan menganut kode praktik GSC. Sebagian besar perkembangan bisnis di seluruh dunia lebih menggunakan proses pasokan produk yang mengancam lingkungan. Proses seperti pembungkusan yang boros dapat menghasilkan bahan kimia beracun terutama pada produk yang akan dikonsumsi oleh konsumen (Hijaz et al. 2015)

Sejauh ini belum diketahui secara pasti jumlah penggunaan pembungkus yang non - green packaging tersebut. Selain itu, kita juga tidak tau, jenis pembungkus manakah yang sering digunakan oleh para UKM untuk mendistribusikan produk mereka tersebut sampai ke tangan konsumen serta alasan - alasan apa saja yang mengakibatkan UKM di sekitar area kampus tetap menggunakan pembungkus non green. Dan melihat keadaan ini, kami pun melakukan observasi pada salah satu Kampus yakni Kampus Unika Soegijapranta untuk mengetahui seberapa banyak pembungkus yang termasuk dalam kriteria non-green packaging yang dihasilkan per harinya yang berada di kantin - kantin atau warung makan khususnya di area dalam dan luar Kampus UNIKA Soegijapranta yang belum menerapkan green packaging ini, dan mengetahui seberapa banyak owner kantin atau warung makan yang sudah mengetahui dan memiliki kesadaran untuk menerapkan green packaging pada proses green supply chain yang dalam hal ini bersedia melakukan penggantian pada pembungkus yang digunakannya saat ini.

\section{KAJIAN PUSTAKA}

Menurut teori Gao et al.,(2009) green production adalah adopsi dan perencanaan kegiatan yang akan membutuhkan lebih sedikit penggunaan energi dan sumber daya dalam sistem produksi dan menyebabkan pencemaran lingkungan paling mungkin. Tujuan Green Manufacturing sendiri untuk terus meningkatkan proses industri dan 
produk dalam rangka untuk mencegah atau mengurangi udara, tanah dan polusi air. Singkatnya, tujuan green manufacturing yaitu untuk menghasilkan produk ramah lingkungan dengan sumber daya minimal (bahan, energi dan air) dan limbah minimal. Green manufacturing adalah salah satu langkah yang paling penting dalam kegiatan GSCM. GSCM sendiri merupakan masalah multidisiplin yang muncul pada dasarnya dari membangun praktek pengelolaan ramah lingkungan dalam konteks rantai pasokan (Rao 2019).

Masalah lingkungan seperti menipisnya sumber daya, polusi lingkungan, pemanasan global dan penurunan keanekaragaman hayati penyebab penurunan keseimbangan ekologi. Fakta bahwa masalah ekologi ini meningkat terus memimpin pemerintah, masyarakat, perusahaan dan individu untuk mengambil tindakan pencegahan dalam hal lingkungan. Perusahaan yang dipandang sebagai sumber masalah lingkungan harus meninjau proses produksi mereka dan rantai pasokan sebagai akibat dari tekanan dari masyarakat dan pemerintah. Seiring dengan penerimaan tanggung jawab perusahaan yang dihasilkan dari kegiatan di seluruh supply chains, green supply chains manufacturing saat ini telah mulai menjadi menonjol (Sezen and Çankaya 2017).

Penelitian sebelumnya telah membuktikan bahwa ini mungkin kesempatan yang lebih baik daripada beberapa uji coba penerapan penghijauan tanpa memiliki tekad yang yakin. Memang, peraturan pemerintah selain permintaan pelanggan yang meningkat berkontribusi dalam meningkatkan pentingnya mempertimbangkan semua masalah lingkungan dalam segala hal mulai dari pengadaan bahan hingga distribusi dalam supply chains dan beberapa institut memperhatikan masalah-masalah umum ini. Namun, sayangnya, hanya sedikit dari mereka yang mengubah keprihatinan ini menjadi tindakan dengan menganut kode praktik GSC. Sebagian besar perkembangan bisnis di seluruh dunia berlanjut menggunakan proses pasokan produk yang mengancam lingkungan. Proses semacam itu seperti pengemasan yang boros dan praktik transportasi yang tidak mencukupi, yang semuanya dapat menghasilkan bahan kimia beracun atau menghasilkan awan gas yang dapat disumbangkan untuk pemanasan global. Setiap tahap dalam rantai pasokan, mulai dari perolehan bahan, manufaktur, pengemasan, penyimpanan hingga logistik dan distribusi; memiliki peluang untuk 
dimodifikasi dan ditingkatkan melalui prinsip-prinsip GSCM untuk mengurangi limbah beracun dan polusi (Hijaz et al. 2015).

Secara umum, dapat dikatakan bahwa konsep GSCM adalah luas, dan tidak ada yang jelas, definisi holistik yang tersedia untuk menggambarkan hal itu. Karena konsep ini didefinisikan secara berbeda oleh para peneliti, sulit untuk menggambarkan GSCM oleh definisi tunggal. Srivastava (2007) melaporkan bahwa GSCM diciptakan dengan masuknya ide pemikiran lingkungan dalam manajemen rantai pasokan. Hal ini mencakup tahap dari desain produk, bahan sumber dan seleksi, proses manufaktur, pengiriman produk dan end-of-life manajemen produk. Seperti yang dapat dipahami dari definisi tersebut dapat dinyatakan bahwa GSCM memiliki area aplikasi yang sangat luas. Namun dalam kebanyakan studi, yang dilakukan di tahuntahun awal, GSCM dipelajari di bawah dimensi fungsional tunggal, seperti Green Purchasing ataupun sebaliknya seperti logistik. Srivastava (2007) melaporkan bahwa GSCM meliputi green packaging, green design, green purchasing, green production, green distribution, logistik, pemasaran dan Reserve Logistics. Menurut Walker et al. (2008), konsep green supply chains meliputi semua tahap siklus hidup produk, dari ekstraksi bahan baku melalui desain, produksi dan distribusi fase, dengan penggunaan produk oleh konsumen dan pembuangannya pada akhir siklus hidup produk. Jelas, praktik GSCM sangat luas. Dalam kesamaan dengan konsep SCM, batas GSCM tergantung pada tujuan dari peneliti (Tseng et al. 2019).

Dalam perwujudan menuju GSCM, selain dimensi GM, green packaging juga merupakan langkah awal tujuan dari GSCM. Green packaging merupakan elemen penting yang tidak hanya karena berkaitan erat dengan komponen lain dari rantai nilai, tetapi juga karena memiliki efek langsung pada lingkungan (Sarkis, 2003). Praktek green packaging sendiri meliputi kemasan sederhana, biodegradabilitas, menghilangkan kemasan berlebihan, penggunaan pembungkus kertas, mengurangi jumlah polystyrene, pembongkaran yang mudah dan penggunaan bahan kemasan disederhanakan (Chiellini 2008).

'Teka - teki' ini menjadi dasar, mengapa selama ini green markets belum lepas landas (bebas) dalam terang perhatian atau kepedulian publik yang kuat untuk perlindungan lingkungan yang dapat dijelaskan demikian: 'kepedulian' publik dan perilaku konsumen yang jauh dari hal 
identik. Seringkali publik mengharapkan intervensi peraturan yang kuat oleh pemerintah untuk menjaga lingkungan, tanpa menarik setiap hubungan yang kuat antara keputusan pembelian masing masing individu dan keadaan seluruh lingkungan mereka (Komisi untuk Kerjasama Lingkungan, 1999). Green packaging sendiri dapat menghasilkan lebih sedikit kerusakan lingkungan daripada bentuk kemasan lainnya, sehingga lebih ramah lingkungan (Chiellini 2008).

Dalam pencapaiannya, green campus merupakan salah satu solusi atau langkah pertama untuk mewujudkan green packaging yang lebih ramah lingkungan. Green campus adalah komunitas pendidikan yang lebih tinggi untuk meningkatkan efisiensi energi, melestarikan sumber daya dan meningkatkan kualitas lingkungan dengan mendidik keberlanjutan dan menciptakan kehidupan yang lebih sehat dalam lingkungan belajar. Green campus yang terus dibangun adalah konsep bidang pendidikan yang memperhatikan isu - isu lingkungan. Sehingga tidak mengherankan bahwa universitas saat ini menerapkan sejumlah kebijakan, diarahkan untuk mendukung upaya untuk menjadi kampus yang ramah lingkungan. Dapat dilihat bahwa, kegiatan staf Universitas dan mahasiswa di kampus akan menghasilkan banyak limbah, karena beberapa program dan penanganan limbah harus menjadi salah satu perhatian Universitas (Setyowati, Kusumawanto, and Prasetya 2018).

\section{METODE PENELITIAN}

\section{Waktu dan Lokasi Penelitian}

Waktu penelitian dilakukan mulai tanggal 13 September 2019 dan 23 September 2019. Lokasi penelitian dilaksanakan pada beberapa kantin di area Universitas Katolik Soegijapranata. Lokasi tersebut dipilih karena peneliti ingin mengetahui intensitas atau seberapa banyak pembungkus yang digunakan kantin di dalam dan di luar Universitas Katolik Soegijapranata Semarang per harinya.

\section{Objek Penelitian}

Objek dalam penelitian ini adalah 50 kantin di dalam dan di luar Universitas Katolik Soegijapranata.

\section{Jenis Penelitian}

Jenis penelitian yang dilakukan adalah penelitian lapangan yaitu dilakukan dengan cara mewawancarai kantin mengenai pembungkus yang dipakai. 


\section{Teknik Pengumpulan Data}

Penelitian ini dilakukan dengan teknik wawancara langsung kepada sampel penelitian. Sampel yang dipilih dalam penelitian menggunakan non probability sampling dengan metode purposive sampling, adapun yang menjadi sampel dari penelitian ini adalah kantin di sekitar Universitas Katolik Soegijapranata, dalam penelitian ini penulis membagi sampel menjadi dua bagian, yang pertama penelitian dilakukan di kantin yang berada di dalam area Universitas Katolik Soegijapranata. Kemudian kantin di dalam Unika dibagi lagi menjadi dua, yaitu kantin di gedung Thomas Aquinas dan kantin yang berada di gedung Henricus Constant, selain di dalam unika penelitian juga dilakukan pada kantin di luar area Unika Soegijapranata dengan batasan kantin yang berada kurang lebih dalam radius 500 meter dari Unika Soegijapranata.

Pertanyaan yang diajukan ke penjual saat wawancara berupa pertanyaan terbuka. Pertanyaan yang diajukan meliputi:

1) Jenis pembungkus apa yang digunakan?

2) Pernah melakukan penggantian pembungkus atau tidak selama berdirinya usaha? (Alasan)

3) Berapa pembungkus yang kira - kira dikeluarkan dalam 1 harinya?
4) Misalnya ada aturan baik dari unika atau dari pemerintah mengenai pembungkus, bersedia atau tidak untuk melakukan penggantian pembungkus? (Alasan)

5) Bila bersedia adakah alternatif pembungkus lainnya?

\section{Analisis Data}

Dari pertanyaan - pertanyaan yang diajukan didapati jawaban yang beragam. Untuk itu peneliti mengubah data kualitatif menjadi data kuantitatif. Tahap - tahap yang dilakukan dalam mengubah jawaban responden ke bentuk kuantitatif dengan cara merekap jawaban di dalam excel, sehingga lebih dapat terukur. Pertama yang dilakukan adalah membaginya ke dalam beberapa kategori, yaitu:

1) Nama kantin

2) Lokasi (Luar Unika, Kantin Unika Thomas Aquinas, dan Kantin Unika Henricus Constant)

3) Jenis makanan/minuman yang dijual

4) Pernah atau tidak melakukan penggantian pembungkus (Pernah atau tidak). Jika menjawab pernah jenis pembungkus apa yang digunakan sebelumnya, dan alasan melakukan penggantian.

5) Jumlah pembungkus per hari per jenis (sterofoam, plastik bening, tempat mika, plastic cup, kresek, sendok plastik, 
sedotan, paper cup, paper bowl/box, kertas minyak coklat, dan kertas putih.)

6) Bersedia melakukan penggantian pembungkus atau tidak (Bersedia atau Tidak Bersedia).

7) Bila bersedia: jenis alternatif pembungkus apa yang akan digunakan.

8) Bila tidak bersedia: alasan tidak bersedia melakukan penggantian

Setelah membagi ke dalam kategorikategori seperti di atas, langkah selanjutnya adalah membagi kategori jumlah pembungkus/hari ke dalam beberapa kategori lagi, yaitu sebagai berikut :

1) Kategori 1: Sterofoam

2) Kategori 2: pembungkus plastik (Plastik bening, tempat mika, plastic cup)

3) Kategori 3: Pelengkap pembungkus (Kresek, sendok plastik, sedotan)

4) Kategori 4: Pembungkus kertas (Paper cup, paper bowl/box, kertas minyak coklat, dan kertas putih)

Dari setiap pembagian ini dapat diketahui secara jelas seberapa besar pembungkus di setiap kategorinya yang dapat dikeluarkan tiap kantin dalam 1 hari, dan dapat diketahui apakah kantin tersebut sudah green atau belum, serta dapat diketahui seberapa banyak penjual yang bersedia melakukan penggantian pembungkus beserta alasannya.

\section{PEMBAHASAN DAN HASIL} PENELITIAN

\section{Kantin di Dalam dan Luar Unika}

Dari hasil wawancara yang telah dilakukan melalui pertanyaan yang diajukan, kemudian diubah menjadi data kuantitatif. Pertanyaan yang diajukan terkait pemahaman penjual mengenai green manufacturing (green pembungkus), pembungkus yang digunakan saat ini, pernah/tidaknya melakukan penggantian pembungkus (beserta alasan) dan kerelaan penjual dalam melakukan penggantian pembungkusnya (beserta alasan). Semua data di bawah merupakan pengeluaran pembungkus dalam 1 hari. Kantin atau pedagang kaki lima yang diwawancarai adalah sebagai berikut:

Tabel 1.

Area Dalam Unika Soegijapranata

\begin{tabular}{|c|c|}
\hline Lokasi Kantin & Nama Kantin \\
\hline \multirow{4}{*}{$\begin{array}{c}\text { Gedung Thomas } \\
\text { Aquinas } \\
\text { (9 kantin) }\end{array}$} & Cupid \\
\cline { 2 - 2 } & The Cozy \\
\cline { 2 - 2 } & Kedai Happy \\
\cline { 2 - 2 } & Populer \\
\cline { 2 - 2 } & Chood Food Café \\
\cline { 2 - 2 } & Crepe 107 \\
\cline { 2 - 2 } & Ludo Café \\
\cline { 2 - 2 } Gedung Henricus & Spicy Chicken \\
\cline { 2 - 2 } Constant \\
(4 kantin) & Gosyen \\
\cline { 2 - 2 } & Carisa Drink \\
\cline { 2 - 2 } & Pondok Makan \\
\hline
\end{tabular}

Sumber: Data Primer yang Diolah 
Tabel 2.

Area Luar Unika Soegijapranata

\begin{tabular}{|c|c|}
\hline Lokasi & Nama Kantin \\
\hline \multirow{14}{*}{$\begin{array}{lr}\text { Area } & \text { Indomaret } \\
(\text { depan } & \text { pintu } \\
\text { masuk Unika) }\end{array}$} & Kaw Tahu \\
\hline & Fremit \\
\hline & Geprek Coy \\
\hline & Starkult \\
\hline & Warung Seribu Rasa \\
\hline & $\begin{array}{lll}\begin{array}{l}\text { Kedai } \\
\text { "Valfa, }\end{array} & \text { Es } & \text { Mini } \\
\end{array}$ \\
\hline & Kuldak \\
\hline & Mak Ndut \\
\hline & $\begin{array}{l}\text { Mie Ayam \& Gado } \\
\text { Gado Gracia }\end{array}$ \\
\hline & Dum \\
\hline & Telur Gulung \\
\hline & Ice Juice Buah \\
\hline & Leker \\
\hline & Terang Bulan \\
\hline \multirow[t]{6}{*}{ Area SPBU Unika } & Cireng Putra Panjalu \\
\hline & Es Pisang Hijau \\
\hline & Batagor Siomay \\
\hline & Khay-khay \\
\hline & Chockles \\
\hline & Oh Coffee \\
\hline \multirow{3}{*}{$\begin{array}{l}\text { Dekat Area } \\
\text { Pujasera Unika }\end{array}$} & Manja Cheese Tea \\
\hline & Warung Katsu Japan \\
\hline & Chicken Run \\
\hline \multirow{8}{*}{$\begin{array}{l}\text { Area Pujasera dekat } \\
\text { Unika }\end{array}$} & Kedai Payon \\
\hline & Ratu Sostel \\
\hline & Oma Thai Tea \\
\hline & King Kone Pizza \\
\hline & $\begin{array}{ll}\text { Mr } & \text { Chicken } \\
\text { Semarang } & \\
\end{array}$ \\
\hline & Cifood \\
\hline & $\begin{array}{ll}\text { Mie } & \text { Semarang } \\
\text { Valentine } & \\
\end{array}$ \\
\hline & Depot makan AS \\
\hline \multirow{5}{*}{$\begin{array}{l}\text { Area dekat } \\
\text { Terowongan } \\
\text { Pawiyatan Luhur }\end{array}$} & Warteg Family \\
\hline & Warteg Aska \\
\hline & Nyoklat \\
\hline & Ayam Geprek Nabila \\
\hline & Seblak Bloom \\
\hline Pintu Keluar Unika & Kedai Twins \\
\hline
\end{tabular}

Sumber: Data Primer yang Diolah
Dari tabel 1 dan 2, terdapat 13 kantin yang berada di dalam area kampus Unika dan 37 kantin yang berada di luar kampus Unika. Sebagaian besar kantin yang berada di area Unika menjual makanan dan minuman. Namun ada beberapa kantin yang hanya menjual makanan saja yaitu seperti Crepe 107, Kuldak, Telur Gulung, Leker, terang Bulan, Cireng Putra Panjalu dan Batagor Siomay. Selain itu juga ada beberapa kantin yang hanya menjual minuman saja yaitu seperti Fremit, Starkult, Dum, Ice Juice Buah, Es Pisang Hijau. Khay-Khay, Cockles, Oh Coffee, Manja Chesee Tea, Oma Thai Tea, dan Nyoklat. Semua kantin tersebut belum menggunakan green pembungkus. Dalam wawancara didapati bahwa sebagian besar menggunakan plastik/sterofoam/kertas untuk pembungkusnya, sehingga dalam penelitian ini penulis membagi jenis pembungkus ke dalam 3 kelompok/jenis (sterofoam, plastik, kertas) dan ada pula pelengkap pembungkus (sendok, sedotan, dll). 


\section{Jenis dan Jumlah Pembungkus}

Tabel 3. Jenis Pembungkus di 50 kantin Kampus Unika Soegijapranata

\begin{tabular}{|l|l|c|}
\hline No & \multicolumn{1}{|c|}{$\begin{array}{c}\text { Jenis } \\
\text { Pembungkus }\end{array}$} & $\begin{array}{c}\text { Jumlah/h } \\
\text { ari }\end{array}$ \\
\hline 1 & Sterofoam & 1000 \\
\hline 2 & Plastik & 2311 \\
\hline 3 & Kertas & 1388 \\
\hline 4 & Pelengkap & 4691 \\
\hline \multicolumn{2}{|c|}{ Total } & 9390 \\
\hline
\end{tabular}

Sumber: Data Primer yang Diolah

Bila ditinjau dari teori Chiellini tentang jenis green packaging maka jenis pembungkus yang digunakan kantin - kantin di sekitar Unika termasuk belum green, kecuali pembungkus kertas. Menurut teori Chiellini dikatakan tidak green karena kemasan tidak dapat digunakan kembali dan bukan merupakan kemasan daur ulang, dalam hal ini kantin - kantin menggunakan kemasan sekali pakai, sebab tidak adanya pengolahan yang dilakukan oleh setiap kantin di sekitar Unika, sehingga baru bisa dikatakan green bila pembungkus yang digunakan dapat digunakan kembali melalui pengolahan tertentu, namun berdasarkan hasil observasi pembungkus yang digunakan langsung dibuang begitu saja. Alasan yang kedua karena pembungkus yang saat ini bukan merupakan kemasan biodegradable, karena tidak mudah terurai dan menghilang ke tanah atau atmosfer, serta dapat menyebabkan kerusakan lingkungan bila tidak melalui pengolahan yang tepat. Karena alasan - alasan ini, sehingga pembungkus di sekitar unika tergolong belum green.

Hal ini sesuai dengan keadaan empiris di lapangan, dari penelitian yang dilakukan menunjukkan bahwa 50 kantin di sekitar Unika (dalam dan luar unika), dalam sehari dapat mengeluarkan $>9000$ pcs bungkus dan pelengkap. Di mana sebagian besar pembungkus yang paling banyak digunakan adalah pembungkus plastik dan pelengkap. Berikut detail pembungkus dan pelengkap yang digunakan penjual, yaitu sebagai berikut:

\section{1) Pembungkus Sterofoam}

Pada tabel 3, kantin yang merupakan penyumbang sterofoam terbesar adalah Kedai $\mathrm{T}$ (luar unika), di mana Kedai $\mathrm{T}$ dalam 1 hari nya dapat mengeluarkan kurang lebih 400 sterofoam. Alasan dari penggunaan sterofoam sendiri karena harga terjangkau, namun sebenarnya pemilik sudah mengetahui akan buruknya penggunaan sterofoam bagi lingkungan ataupun kesehatan manusia. 


\section{2) Pembungkus Plastik}

Tabel 4. Penggunaan Pembungkus Plastik di Dalam dan Luar Unika Soegijapranata

\begin{tabular}{|l|l|c|}
\hline No & \multicolumn{1}{|c|}{$\begin{array}{c}\text { Pembungkus } \\
\text { Plastik }\end{array}$} & Jumlah/hari \\
\hline 1 & Plastik bening & 771 \\
\hline 4 & Tempat Mika & 135 \\
\hline 6 & Plastic Cup & 1405 \\
\hline \multicolumn{2}{|c|}{ Total } & 2311 \\
\hline
\end{tabular}

Sumber: Data Primer yang Diolah

Kantin yang menggunakan bungkus berbahan dasar plastik masih banyak ditemui. Plastik merupakan penggunaan pembungkus terbesar dibandingkan penggunaan pembungkus berbahan dasar lain. Pembungkus plastik sendiri terdiri dari plastik bening, tempat mika, dan plastic cup. Penggunaan dari plastic cup merupakan penggunaan paling banyak dibandingkan yang lainnya karena mayoritas kantin sudah tidak lagi menggunakan plastik bening untuk minuman melainkan sudah beralih ke plastic cup.

Kedai $\mathrm{T}$ adalah kantin yang berada di luar kampus di mana penggunaan pembungkus plastik khususnya plastic cup terbanyak yaitu sejumlah $350 \mathrm{pcs} /$ harinya. Pengguna plastic cup terbanyak kedua adalah kantin GFC yang menjual teh poci. GFC dalam satu harinya bisa menggunakan 250 plastic cup.

Dari hasil observasi penyebab penggunaan plastik bening bisa mencapai jumlah tersebut, salah satu faktornya adalah penggunaan berlebihan dari plastik bening, contoh nyatanya ada di salah satu kantin hasil observasi yang menjual soto. Di kedai $\mathrm{V}$ ini, penjual menggunakan kurang lebih 3 - 5 plastik bening denagn ukuran yang berbeda-beda (plastik digunakan untuk membungkus kuah soto, mie, kecap, dan sambal), belum lagi ditambah kresek sebagai pembungkus terluarnya. Sehingga tidak heran bahwa jumlah penggunaan plastik sangat banyak di dalam dan luar kantin Unika Soegijapranata.

\section{3) Pembungkus Kertas}

Tabel 5. Penggunaan Pembungkus Kertas di Dalam dan Luar Unika Soegijapranata

\begin{tabular}{|c|l|c|}
\hline No & $\begin{array}{c}\text { Pembungkus } \\
\text { Kertas }\end{array}$ & Jumlah/hari \\
\hline 1 & Paper cup & 65 \\
\hline 2 & Paper bowl/box & 55 \\
\hline 3 & $\begin{array}{l}\text { Kertas minyak } \\
\text { coklat }\end{array}$ & 1188 \\
\hline 4 & Kertas Putih & 80 \\
\hline
\end{tabular}

Sumber: Data Primer yang Diolah 
Selain pembungkus yang berbahan dasar sterofoam dan plastik, di area sekitar kampus Unika Soegijapranata juga menggunakan berbahan dasar kertas. Pembungkus kertas sendiri terdapat empat jenis yaitu paper cup, paper bowl/box, kertas minyak coklat, dan kertas putih. Dari keempat jenis pembungkus kertas, kertas minyak coklat merupakan pembungkus ynag paling banyak digunakan. Dari hasil survey yang ada, kertas minyak coklat paling banyak digunakan oleh Warung Tegal seperti Warteg F yang menggunakan 250 pcs/hari dan Warteg A yang menggunakan 150pcs/hari. Selain itu, Kedai $\mathrm{T}$ juga merupakan pengguna kertas minyak coklat paling banyak kedua setelah Warteg F yaitu sebanyak 225pcs/hari. Penggunaan kertas mintak coklat biasanya juga diikuti dengan penggunaan sterofoam dimana kertas minyak cokllat ini digunakan sebagai alas.

\section{4) Pelengkap Pembungkus}

Dari hasil wawancara diketahui ternyata tidak hanya pembungkus saja yang dikeluarkan penjual, namun di samping itu terdapat penggunaan lain yaitu pelengkap seperti sendok plastik, sedotan, dan kresek yang penggunaannya melebihi 4000/pcs per hari nya. Dari hasil penelitian, 50/50 penjual menyediakan kresek.
Tabel 6. Penggunaan Pembungkus Pelengkap di Dalam dan Luar Unika Soegijapranta

\begin{tabular}{|c|l|c|}
\hline No & Pelengkap & $\begin{array}{c}\text { Jumlah/h } \\
\text { ari }\end{array}$ \\
\hline 1 & Kresek & 2077 \\
\hline 2 & Sendok Plastik & 1368 \\
\hline 3 & Sedotan & 1246 \\
\hline \multicolumn{2}{|c|}{ Total } & 4691 \\
\hline
\end{tabular}

Sumber: Data Primer yang Diolah

\section{5) Kemungkinan Penggantian Pembungkus}

Tabel 7. Kesediaan Penjual dalam Penggantian Pembungkus

\begin{tabular}{|c|c|c|}
\hline No & $\begin{array}{c}\text { Bersedia } \\
\text { mengganti } \\
\text { Pembungkus/ti } \\
\text { dak }\end{array}$ & Jumlah \\
\hline 1 & Bersedia & 25 \\
\hline 2 & Tidak Bersedia & 32 \\
\hline
\end{tabular}

Sumber: Data Primer yang Diolah

Hasil penelitian menunjukkan bahwa sebagian besar penjual belum bersedia untuk melakukan penggantian pada pembungkus. Dari hasil wawancara, faktor-faktor yang mempengaruhi penjual belum bersedia antara lain adalah

1. Plastik dan streofoam merupakan pembungkus yang biayanya paling rendah 
dibandingkan dengan green packaging sehingga penjual mampu memperoleh margin laba maksimal.

2. Plastik dan sterofoam masih beredar di pasaran sehingga anggapan penjual adalah pembungkus-pembungkus tersebut masih boleh dipakai.

3. Regulasi pemerintah yang tidak sinkron antara penjual yang tidak boleh menggunakan sterofoam namun industri sterofoam masih diperbolehkan berproduksi oleh pemerintah.

Walaupun masih banyak penjual yang belum bersedia, tidak dipungkiri bahwa terdapat beberapa penjual yang sudah mau bersedia untuk melakukan penggantian pembungkus. Sebagai contoh warung K saat ini sudah melakukan penggantian pembungkus selang $\pm 1,5$ bulan setelah wawancara kami lakukan, warung $\mathrm{K}$ bersedia melakukan penggantian dari sterofoam ke food grade dikarenakan penjual sadar mengenai pembungkus yang non-green akan berdampak buruk bagi kesehatan tubuh manusia dan juga merusak lingkungan. Selain dari kesadaran hal tersebut, kantin lain di sekitar unika yang menjawab bersedia mengganti pembungkusnya mengatakan bersedia mengganti bila ada aturan yang tegas yang diterapkan oleh pihak pemerintah atau instansi - instansi terkait seperti Unika Soegijapranata yang lokasinya sangat dekat dengan para penjual. Di samping itu, penjual bersedia melakukan penggantian pembungkus bila adanya dukungan dari pemerintah untuk menyediakan pembungkus yang ramah lingkungan namun juga dengan harga yang dapat dijangkau konsumen. Karena penggantian pembungkus dari non green menjadi green packaging akan berdampak pada harga jual dari produk mereka ataupun biaya green packaging dibebankan kepada konsumen sebesar $\mathrm{Rp}$ 1.000 - Rp2.000

\section{KESIMPULAN DAN SARAN KESIMPULAN}

Dari hasil penelitian yang dilakukan diketahui bahwa kantin di sekitar Unika tidak ada yang benar - benar menerapkan Green Manufacturing, dikarenakan kantin yang sudah menggunakan green packaging pun (contoh : KT - menggunakan pembungkus kertas) masih tetap mengeluarkan plastik seperti kresek/sedotan/sendok plastik, sehingga diketahui bahwa sebagian besar penjual masih bergantung pada pembungkus yang tergolong non - green ini. 
Berdasarkan observasi yang telah ditemuka, intensitas penggunaan pembungkus di dalam dan luar Unika Soegijapranata dalam per harinya bisa mencapai 9390 pembungkus ( sterofoam, plastik, kertas, dan pelengkap), sehingga dalam satu bulan kurang lebih sebesar 187.800 pembungkus ( 9.390 pembungkus $\mathrm{x}$ 20 hari efektif kerja).

Sebenarnya saat wawancara sebagian besar penjual makanan atau minuman di sekitar Unika bersedia mengganti pembungkusnya bila ada aturan yang tegas yang diterapkan oleh pihak pemerintah atau instansi - instansi terkait seperti Unika Soegijapranata yang lokasinya sangat dekat dengan para penjual. Hal ini sesuai karena, saat ini sebagian besar kantin di dalam Unika khususnya kantin di Gedung Thomas Aquinas sudah tidak menggunakan sterofoam lagi, karena adanya aturan dari pihak unika yang melarang penggunaan sterofoam, namun hal ini nampaknya belum begitu berlaku bagi kantin di gedung Henricus Constant karena tidak adanya peraturan yang ketat di sana

Selain alasan aturan yang tegas, penjual bersedia melakukan penggantian pembungkus bila adanya dukungan dari pemerintah untuk menyediakan pembungkus yang ramah lingkungan namun juga dengan harga yang dapat dijangkau konsumen. Sebagian besar penjual enggan beralih ke green pembungkus karena mereka otomatis akan mengeluarkan biaya yang lebih besar untuk menjalankan usahanya, dan hal ini dirasa cukup merugikan bagi penjual.

\section{SARAN}

Dengan adanya penelitian ini, kami sebagai peneliti mencoba untuk memberikan saran bagi:

\section{Pemerintah}

Pemerintah lebih berusaha untuk menegakkan peraturan bilamana adanya larangan penggunaan pembungkus yang berbahaya bsgi lingkungan. Penegakan peraturan ini diikuti dengan tidak mengijinkan produsen yang masih memproduksi pembungkus berbahaya tersebut. Selain itu, pemerintah juga mencari pembungkus substitusi selain sterofoam ataupun plastik yang mempunyai nilai ekonomis yang sama sehingga penjual tidak merasa terbebani jika diharuskan tidak boleh menggunakan sterofoam ataupun plastik.

Selain itu pihak pemerintah harus mempunyai cara yang tepat untuk melakukan pengolahan terhadap pembungkus yang telah digunakan. 
Implementasi ini harus dilakukan secara merata sehingga nantinya masyarakat mulai terbiasa dan bisa menjadi suatu budaya yang dapat tertanam

\section{Penjual}

Sebagai penjual, lebih baik jika tetap memperhatikan lingkungan sekitar sehingga alam akan tetap terjaga dengan melakukan penggantian pembungkus yang lebih green, seperti menggunakan pembungkus food grade.

\section{Konsumen}

Pada zaman sekarang ini, konsumen akan jauh lebih baik bila mampu untuk memilih produk yang baik. Produk yang baik juga terlihat dari pembungkus yang baik bagi lingkungan dan kesehatan. Walaupun terdapat perbedaan harga, namun hal ini merupakan investasi jangka panjang bagi kesehatan dan lingkungan sekitar kita.

\section{Peneliti}

Bagi peneliti berikutnya, penelitian mengenai pembungkus pada kantin -kantin di sekitar Unika masih dapat diolah kembali mengenai masalah bersedia atau tidaknya konsumen menggunakan green packaging. Sehingga antara penelitian ini dan penelitian berikutnya terjadi hubungan dua arah yang melihat bersedia atau tidaknya penjual dan konsumen untuk menggunakan green packaging

\section{DAFTAR PUSTAKA}

Reni Amaranti, Drajad Irianto, Rajesri Govindaraju. 2014. Green Manufacturing: Kajian Literatur. [Internet]. Tersedia di: https://idec.ft.uns.ac.id/wpcontent/uploads/2017/11/Prosiding2017 _ID030.pdf

Yahaya, R., \& Ebrahim, F. (2016). Leadership styles and organizational commitment: literature review. Journal of Management Development. https://doi.org/10.1108/JMD-01-20150004

Chiellini, Emo. 2008. Environmentally Compatible Food Pembungkus Environmentally Compatible Food Pembungkus.

Hijaz, Suzan, Omar Al-Hujran, Mutaz M. Al-Debei, and Nour Abu-Khajil. 2015. "Green Supply Chain Management and SMEs: A Qualitative Study." International Journal of Business Information Systems 18(2): 198-220.

Rao, Purba Halady. 2019. "Green Supply Chain Management: A Study Based on SMEs in India." Journal of Supply Chain Management 8(1): 15-24.

Rokka, Joonas, and Liisa Uusitalo. 2008. "Preference for Green Pembungkus in Consumer Product Choices - Do Consumers Care?" International Journal of Consumer Studies 32(5): 516-25.

Setyowati, Mega, Arif Kusumawanto, and Agus Prasetya. 2018. "Study of Waste Management towards Sustainable Green Campus in Universitas Gadjah Mada." Journal of Physics: Conference Series 1022(1). 
Sezen, Bülent, and Sibel Yildiz Çankaya. 2017. "Green Supply Chain Management Theory and Practices." Operations and Service Management: Concepts, Methodologies, Tools, and Applications: 118-41.

Toolkit, Environmental Policy. 2016. "Greening SMEs Environmental." (March).

Tseng, Ming Lang et al. 2019. “A Literature Review on Green Supply Chain Management: Trends and Future Challenges." Resources, Conservation and Recycling 141(February): 145-62. https://doi.org/10.1016/j.resconrec.2018 .10.009. 